\title{
Mutuality on a spectrum: Ownership and Buy-In
}

\author{
Michael Cornell*
}

\section{Introduction}

Mutuality in leadership is the intangible element that connects leaders and followers together. Mutuality produces lasting results from the relationship of shared goals between leader and follower. However, there are degrees of mutuality that will dictate the type and longevity of a result. Buy-in and ownership are two degrees of mutuality that need dissection in order to understand the link between leaders and followers. Buy-in and ownership are often used interchangeably, but the application of each in relationship to mutuality differ significantly. Ownership experienced by the leader and follower creates space for the leader and the follower to develop a shared goal. The follower is able promote the leader's position, bringing others into the fold. Buy-in can be mechanical, whereby the leader institutes a plan and the follower accepts the proposal for a lack of better options.

Assigning what constitutes buy-in or ownership as degrees of mutuality, one has to look at what drives leaders and followers to forge relationships. The impacts of power and vision on the leadership relationship strengthen the direction of mutuality. Ownership and buy-in require a balance in the relationship for when left un-checked, abuse of the degrees of mutuality can occur. These degrees of mutuality hinge on the appropriate use of power and the follower's acceptance of the leader's position. The leaders present their version of vision and whether they chose to include or exclude the followers in the creative process can determine the difference between long-term success and short-term gains. The leadership relationship between leaders and followers therefore depends on application of ownership and buy-in as degrees of mutuality.

\section{Ownership: Leaders and Followers}

Ownership as a degree of mutuality binds leaders and followers within a similar space. The literature on the role that ownership plays in the relationship between leader and follower is thin, however an attempt must be made to understand how "owning" can affect the overall relationship and the outcome. ${ }^{1}$ Ownership in this context refers to acknowledging, accepting

\footnotetext{
1 Avolio, Bruce J. and Rebecca J. Reichard (2008), 'The Rise of Authentic Followership', Ronald Riggio, Ira Chaleff and Jean Lipman Blumen, eds., The Art of Followership, How
} 
and advocating an idea or concept. Follower ownership has benefits beyond the leader's obvious paybacks to owning their own ideas or processes. Once a follower enacts the leader's strategies towards other people, they end up promoting the leader. ${ }^{2}$ Accepting and promoting a leader's position reduces the burden on the leader to encourage participation from more followers. This degree of ownership provides the leader space to operate. From the follower's perspective, they are 'an active agent who, through social construction processes with leaders, facilitates mutual goal attainment'. 3 Promoting the leader's position and acceptance fulfils a "void" for the follower. When a follower is able to identify with an idea or concept, they begin to own what the leader is trying to deliver. ${ }^{4}$

\section{Ownership: Vision and Power}

An integral part of the equation in obtaining mutuality requires vision creation and an acceptable use of power. The leader must deliver a clear vision and use power wisely, without losing the trust of the followers. Vision and power are parts of the equation that determines durability, as 'vision is the commodity of leaders, and power is their currency'. ${ }^{5}$ Presenting a vision from the top-down is the typical delivery method, however the follower is left out of the design phase. While the ways to implement vision will vary, the inclusion of followers in the creation and initiation processes can generate ownership, for it will have been a collaborative effort. ${ }^{6}$ Leaders win for they can guide the conversation, and followers win because they are involved in the process.

The type of power used and accepted influences the degree of ownership in mutuality. Leaders can use referent power and expert power to influence followers through identifying with a group and providing key information to the situation that otherwise might be absent. ${ }^{7}$ However, leaders must be careful in their use of power for trust is a fragile commodity. When the

Great Followers Create Great Leaders and Organizations, (San Francisco, CA: Jossey-Bass), p. 328

2 Zoogah, David B. (2014), Strategic Followership, How Followers Impact Organizational Effectiveness, (New York, NY: Palgrave Macmillan), p. 57

3 Zoogah (2014), p 41

${ }^{4}$ Avolio, Reichard (2008) p. 332

5 Bennis, Warren \& Nanus, Burt (1985), Leaders, The Strategies for Taking Charge, (New York, NY: Harper \& Row Publishers), p. 18

${ }^{6}$ Carsten, Melissa K. and Michelle C. Bligh, (2008), 'Lead, Follow and Get out of the Way: Involving Employees in the Visioning Process', Ronald Riggio, Ira Chaleff and Jean Lipman Blumen, eds., The Art of Followership, How Great Followers Create Great Leaders and Organizations, (San Francisco, CA: Jossey-Bass), p. 280

7 Yukl, Gary (2013), Leadership in Organizations, Global Edition, $8^{\text {th }}$ edn., (Essex, England: Pearson), pp. 193-194 
application of power is exploited, leaders lose the trust of those they lead, as they failed to '[understand] that as leaders, they can only really be effective if they retain the willingness of those...they lead......$^{8}$ Leader and follower stewardship of ownership is a balancing act of shared cooperation and attainment of similar goals that benefit both sides.

\section{Buy-In: Leaders and Followers}

Buy-in, on the surface, could be synonymous with ownership. However, there is a transactional element to the phrase. Either one side or both sides have to adjust their position to align with the other, often times under circumstances unfavourable. This does not imply that the idea or goal is unacceptable to either leader or follower, it simply means the follower may not be charmed by the message, but the alternative could be seen to be worse. ${ }^{9}$ From the leader's view, if enough energy is expended to warrant a commitment of some sort, that should be enough to accomplish a goal. This degree of mutuality still allows for goal attainment, but the connections are weaker. The follower will tolerate much more in this relationship if they are limited in choices. ${ }^{10}$ The leader will expend energy only in so far as to accomplish short term goals and interests. ${ }^{11}$ The longevity of this degree of mutuality is questionable because either one side or both remain suspicious of the other's motive.

\section{Buy-In: Vision and Power}

This unsteady relationship is further muddled by the lack of joint vision creation and use of power. Followers who receive the vision in a top-down manner without providing input are less likely to accept the sum of the vision, and more likely to reject alignment and find fault with the organization or leader. ${ }^{12} \mathrm{An}$ error that leaders can make when developing a vision is believing that the input of the follower is not important. The assumption that the follower is not capable of providing advice to the leader continues the stereotype of the leader role as being in a superior position..$^{13}$ Power usage in this degree of mutuality creates a tenuous atmosphere. The leader typically will use various forms of legitimate, coercive and reward

\footnotetext{
${ }^{8}$ Bones, Christopher (2011), A Cult of the Leader, A Manifesto for More Authentic Business, (West Sussex, UK: John Wiley \& Sons, Ltd., Publication), p. 122

${ }^{9}$ Kellerman, Barbara (2008), Followership: How Followers are Creating Change and

Changing Leaders, (Boston, Massachusetts: Harvard Business Press), p. 72

${ }^{10}$ Senett, Richard (1980), Authority, (New York: Alfred A. Knopf Inc.), p. 107

${ }^{11}$ Sennett (1980), p. 82

12 Carsten and Bligh, (2008) p. 280

${ }^{13}$ Zoogah (2014), pp. 40-41
} 
power to achieve their goals through use of authority, resources and threats. ${ }^{14}$ Power used in this manner can be transactional in nature, effectively a "buy-in" of the follower to the leader to prevent a situation from turning worse. The leader is able to maintain their position by minimal effort. A leader can then become autonomous, disconnected from the followers, less likely be held accountable, and lose alignment with the followers. ${ }^{15}$ The leader through this degree of mutuality can claim leadership and accomplish goals, albeit at a reduced rate of mutuality. People will follow the leader under normal situations, and even when the leader is viewed as wrong, they will still follow for lack of choice. ${ }^{16}$ This degree of mutuality may result in goal attainment and success claimed, but the issue then becomes for "how long" and "at what cost".

\section{Degrees of Mutuality}

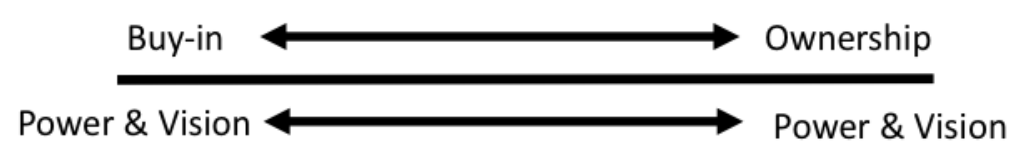

\section{Ownership and Buy-In Exploited}

Figure 1 demonstrates where buy-in and ownership exist on a spectrum. The various methods of power usage and vision exist along the same spectrum and operate in conjunction with buy-in and ownership. Reference was made earlier in regard to the impact that ownership and buy-in have as degrees of mutuality when executed inadequately. What will happen if both degrees of mutuality are taken to their extremes? Ownership comes in various forms, most understandably as a tangible object, but it is 'multidimensional in nature...it also exists psychologically as an

\footnotetext{
${ }^{14}$ Yukl (2014), pp. 191-193

${ }^{15}$ Senett (1980), p. 86

16 Kellerman (2008), p. 17
} 
experienced state'. ${ }^{17}$ If this "experienced state" is blindly accepted from the leader/follower relationship, a dangerous form of ownership is created. A form where balance is neglected for the excitement of what is being presented, regardless of practicality. To accept blindly the actions of the leader allows for the abuse of power because anything that occurs can be explained away. On the other end, if ownership is managed too tightly, the power mechanisms applied could be used to abuse the very people whom they seek to influence. A breaking point will be reached in which the followers will have to decide how much to keep providing the leader.

Buy-in should not be considered the least desirable degree of mutuality. It is only a form that the relationship takes between the leader and follower in the pursuit of a goal. The connections one feels towards a leader, group or organisation allows them to sense a belonging to something and thus make them, at least in their eyes, a valuable member of the unit. ${ }^{18}$ The feeling of belonging can be faked to present a false sense of acceptance. The followers could pretend to agree just to avoid a more uncertain outcome. Leaders can abuse their use of power long enough to force followers to accept their fate. Buy-in requires less work on behalf of the leader for they can use their power to prescribe terms and gain "just enough" commitment. Followers usually accept, mainly because they see no other option. If buy-in as a degree of mutuality is not monitored, it can be abused to create a situation unfavourable to the followers. Ownership requires continual engagement for if the checks and balance are exercised incorrectly, it will not allow for a harmonious relationship.

\section{Conclusion}

Ownership and buy-in as degrees of mutuality are key elements in understanding how the leadership relationship works. The relationship parameters are not strictly limited to either the leader or follower. Both have a role in the execution of leadership. The notion of vision and power are only two of the key elements that are used to build the relationship and allow for leadership to be exercised. With a united vision and appropriate use of power, ownership is experienced by both leader and follower. The follower executes and promotes the leader's vision, the leader in turn is

\footnotetext{
17 Pierce, Jon L. and Jussila Iiro (2011), Psychological Ownership and the Organizational Context: Theory, Research Evidence and Application, (Cheltenham, UK: Edward Elgar Publishing Limited), p. 162

18 Wheatley, Margaret J. (2006), Leadership and the New Science, Discovering Order in a Chaotic World, Third Edition (San Francisco, CA: Berrett-Koehler Publishers, Inc.), p. 68
} 
relieved of the burden of having to convince people of their cause. When the vision is one-sided, and elements of power are abrasive in nature, followers may still follow, but out of reluctance because there is no better alternative. Leaders gain compliance with minimum effort and results are achieved, though these are generally short-termed. When both ownership and buy-in are taken to their extremes, blind acceptance or faked, an environment is created in which certainty and sustained success are no longer visible. At this point of uncertainty, the mutuality in the leadership relationship has shifted unchecked to one side. What exists in this scenario is hysteria or contempt for the leader and/or followers. For buy-in to occur, a leader needs to understand what the followers will accept and present accordingly. The followers must be willing to settle for what is presented. For ownership to occur, a leader must establish a clear vision with the inclusion of the followers and use their power correctly. The follower must accept what the leader is proposing and promote it. The degree of mutuality achieved between the leader and follower determines to what extent the relationship can flourish.

\section{*African Leadership Centre, King's College London}

\section{BIBLIOGRAPHY}

Avolio, Bruce J. and Rebecca J. Reichard (2008), 'The Rise of Authentic Followership', Ronald Riggio, Ira Chaleff and Jean Lipman Blumen, eds., The Art of Followership, How Great Followers Create Great Leaders and Organizations, (San Francisco, CA: Jossey-Bass)

Bennis, Warren \& Nanus, Burt (1985), Leaders, The Strategies for Taking Charge, (New York, NY: Harper \& Row Publishers)

Bones, Christopher (2011), A Cult of the Leader, A Manifesto for More Authentic Business, (West Sussex, UK: John Wiley \& Sons, Ltd., Publication)

Carsten, Melissa K. and Michelle C. Bligh, (2008), 'Lead, Follow and Get out of the Way: Involving Employees in the Visioning Process', Ronald Riggio, Ira Chaleff and Jean Lipman Blumen, eds., The Art of Followership, How Great Followers Create Great Leaders and Organizations, (San Francisco, CA: Jossey-Bass)

Kellerman, Barbara (2008), Followership: How Followers are Creating Change and Changing Leaders, (Boston, Massachusetts: Harvard Business Press) 
Pierce, Jon L. and Iiro Jussila (2011), Psychological Ownership and the Organizational Context: Theory, Research Evidence and Application, (Cheltenham, UK: Edward Elgar Publishing Limited)

Senett, Richard (1980), Authority, (New York: Alfred A. Knopf Inc.). Wheatley, Margaret J. (2006), Leadership and the New Science, Discovering Order in a Chaotic World, $3^{\text {rd }}$ edn. (San Francisco, CA: Berrett-Koehler Publishers, Inc.)

Yukl, Gary (2013), Leadership in Organizations, Global Edition, $8^{\text {th }}$ edn., (Essex, England: Pearson)

Zoogah, David B. (2014), Strategic Followership, How Followers Impact Organizational Effectiveness, (New York, NY: Palgrave Macmillan) 